\title{
Personalized therapies in the cancer "omics" era
}

\author{
Alberto Ocaña ${ }^{1,2}$, Atanasio Pandiella $3^{3^{*}}$
}

\begin{abstract}
A molecular hallmark of cancer is the presence of genetic alterations in the tumoral DNA. Understanding how these alterations translate into the malignant phenotype is critical for the adequate treatment of oncologic diseases. Several cancer genome sequencing reports have uncovered the number and identity of proteins and pathways frequently altered in cancer. In this article we discuss how integration of these genomic data with other biological and proteomic studies may help in designing anticancer therapies "a la carte". An important conclusion is that next generation treatment of neoplasias must be based on rational drug combinations that target various pathways and cellular entities that sustain the survival of cancer cells.
\end{abstract}

\section{Review}

A critical step towards defining a correct personalized anticancer therapy is the identification of the genes and pathways altered in the tumour of the patient, and the elucidation of their particular oncogenic role. The success of molecular studies in identifying potential molecular targets for therapeutic intervention is exemplified by the developments in the treatment of chronic myelogenous leukaemia (CML) [1]. This disease is characterized by the presence of the Philadelphia chromosome, created by a translocation which provokes constitutive activation of the tyrosine kinase Abl. The identification of this molecular alteration fostered the development of drugs such as Imatinib Mesylate that inhibit Abl kinase activity and successfully control the disease [2]. However, in most solid tumours multiple genetic lesions are expected to be required for tumour progression [3]. In fact, the clinical experience in the treatment of oncologic diseases indicates that combinations of drugs that act on different cellular targets demonstrate superiority over single agent-based treatments [4]. Yet, these combined treatments are mostly based on empirical trials and lack, in many instances, a biological rationale $[5,6]$. Given the positive experience that molecular knowledge has offered for the treatment of CML, efforts have been made to define the molecular alterations present in the DNA of distinct types of tumours. Here we will comment how novel high throughput techniques may help

\footnotetext{
* Correspondence: atanasio@usal.es

${ }^{3}$ Instituto de Biología Molecular y Celular del Cáncer, CSIC-Universidad de Salamanca, Salamanca, Spain
}

in finding more adequate and less toxic personalized anticancer therapies.

\section{Somatic alterations in the cancer genome}

In designing proper anticancer therapies the clinical and the preclinical researchers face several important questions: How many genetic alterations exist in a tumour? How many of them are responsible of promoting tumour growth? How many should be targeted to eradicate the tumour? The availability of technologies that allow large scale sequencing and genomics analyses of several tumours, together with strong bioinformatics tools and functional studies are contributing to answering these questions. Recent studies on the molecular profiling of breast and colon $[7,8]$, lung [9-11], glioblastoma [12,13] and pancreatic [14] cancers have described alterations in multiple genes and pathways important for the control of cell number in these tumours. Although this is an already known concept, the value of these studies is that by sequencing of the whole transcriptome of individual tumours the researchers have uncovered the number of mutated genes as well as their identity. In the analysis of the genomes of breast and colorectal cancers [7], between 60 and 80 mutations that alter the amino acid sequence of proteins (non-silent mutations) were detected in a single tumour (Table 1). Noteworthy, although some of the genes were overlapping, most of them were not coincident, not only when comparing breast and colon tumours, but also when comparing tumours of the same type but from distinct patients. It should however be mentioned that these transcriptomic sequencing studies, while offering important molecular information on individual 
Table 1 Somatic mutations in cancer exomes and pathways affected

\begin{tabular}{|c|c|c|c|c|}
\hline $\begin{array}{l}\text { Tumour type } \\
\text { (sample size) }\end{array}$ & $\begin{array}{l}\text { Genes } \\
\text { analyzed }\end{array}$ & $\begin{array}{l}\text { Average number of } \\
\text { mutated genes/ } \\
\text { patient }\end{array}$ & Major pathways deregulated & References \\
\hline Breast $(n=11)$ & 18,191 & 62 & RTKs, PI3K, NF $\kappa$ B, & [7] \\
\hline $\begin{array}{l}\text { Colorectal cancer } \\
(n=11)\end{array}$ & 18,191 & 88 & RTKs, PI3K, Cell adhesion, Cytoskeleton, Extracellular matrix & [7] \\
\hline $\begin{array}{l}\text { Colorectal cancer } \\
(n=1)\end{array}$ & Genome & 292 & Transcription (SPDEF), Metalloproteases (MMP28), PI3K, BRAF & [16] \\
\hline $\begin{array}{l}\text { Glioblastoma }(n= \\
\text { 22) }\end{array}$ & 20,661 & 47 & $\begin{array}{l}\text { RTKs, PI3K, Cell cycle, DNA damage (p53), Neuronal-type pathways } \\
\text { (ionic channels), IDH1 }\end{array}$ & [13] \\
\hline Pancreas $(n=24)$ & 20,661 & 48 & $\begin{array}{l}\text { KRAS signalling, DNA damage control, Cell cycle, TGF } \beta \text { pathway, Wnt/ } \\
\text { Notch signalling, Cell adhesion and integrin signalling, MAPK signalling, } \\
\text { Apoptosis }\end{array}$ & [14] \\
\hline $\begin{array}{l}\text { Glioblastoma }(n= \\
\text { 206) }\end{array}$ & $\begin{array}{l}601 \text { selected } \\
\text { genes }\end{array}$ & NA & RTKs, NF1, DNA damage, PI3K, Cell cycle, methylation, mismatch repair & [12] \\
\hline $\begin{array}{l}\text { Lung cancer }(n= \\
\text { 188) }\end{array}$ & $\begin{array}{l}623 \text { genes } \\
\text { implicated in } \\
\text { cancer }\end{array}$ & NA & $\begin{array}{l}\text { RTKs, DNA damage control, RAS (K and N), NF1, LRP1B (lipid } \\
\text { metabolism), MAPK signalling, Wnt signalling, STK11 (Ser/Thr kinase) }\end{array}$ & [10] \\
\hline $\begin{array}{l}\text { Lung cancer }(n= \\
371)\end{array}$ & NA & NA & $\begin{array}{l}\text { Cell cycle, PI3K, RTKs, Tyrosine phosphatases, cAMP, Angiogenesis, } \\
\text { NKX2-1 (pneumocyte differentiation) }\end{array}$ & [9] \\
\hline $\begin{array}{l}\text { Lung cancer }(n= \\
\text { 1) }\end{array}$ & Genome & 134 & Cell cycle (Rb), DNA damage (p53), DNA helicase CHD7 & [11] \\
\hline $\begin{array}{l}\text { Mesothelioma }(n= \\
\text { 4) }\end{array}$ & 15,000 & 6 & $\begin{array}{l}\text { DNA damage, Extracellular matrix, Mitochondrial reductase activity, } \\
\text { proteasome, Apoptosis }\end{array}$ & [54] \\
\hline $\begin{array}{l}\text { Diverse cancers ( } n \\
=210)\end{array}$ & 518 kinases & NA & RTKS, JNK, MAPK "BRAF, DNA damage control & [20] \\
\hline $\begin{array}{l}\text { Renal cancer, clear } \\
\text { cell }(n=101)\end{array}$ & 3544 & NA & $\begin{array}{l}\text { Histone modifications (SETD2, JARID1C, UTX), VHL, NF2, HIF1A, PMS1 } \\
\text { (DNA mismatch repair), WRN and NBN (DNA double strand repair) }\end{array}$ & [55] \\
\hline $\begin{array}{l}\text { Diverse cancers ( } n \\
=3131)\end{array}$ & NA & NA & $\begin{array}{l}\text { Kinases, cell cycle, NF } \kappa \mathrm{B}, \mathrm{Myc} \text {, Apoptosis, Cell adhesion, DNA } \\
\text { methylation, microtubule organization, transcription }\end{array}$ & [22] \\
\hline $\begin{array}{l}\text { Acute Myeloid } \\
\text { leukaemia }((n=1)\end{array}$ & Genome & 10 & NRAS, NPM1, IDH1, CDC42, IMPG2, ANKRD46, LTA4H, FREM2, CEP170 & {$[17,18]$} \\
\hline $\begin{array}{l}\text { Ovarian granulosa } \\
\text { cell tumours }(n= \\
\text { 4) }\end{array}$ & Genome & NA & FOXL2 & [56] \\
\hline
\end{tabular}

tumours, must be complemented with other genomic analyses, as they may, for example, miss the overexpression of non-mutated HER2 that is present in one out of four patients with breast cancer, and that represents a relevant clinical target [15]. Another more recent study identified a larger number (292 mutations in coding regions, of which 187 were non-synonymous) of mutated genes in a cell line of colorectal cancer [16]. It is possible that these differences may stem from the fact that some works reported results from patients, while others used cell lines which may accumulate lesions along their in vitro establishment. On the other side, sequencing of acute myeloid leukaemia (AML) samples have identified 10 mutations in proteincoding mRNAs $[17,18]$. Additional massive sequencing efforts, such as those carried out by the International Cancer Genome Consortium, will help in establishing a more accurate measurement of the average mutated genes/ tumour.
By using bioinformatics analyses those authors indicated that most of the mutations in an individual breast or colon tumour were silent in terms of favouring tumour progression [7]. These analyses indicated that not more than 15 genes, that they term CAN genes (from "cancer" genes), are responsible for supporting tumour viability in each tumour. Some of the mutations identified affected genes that participate in the PI3K or $\mathrm{NF} \kappa \mathrm{B}$ routes, two pathways linked to cell survival/proliferation, and that are potential therapeutic targets (Table 2). An important question that must be addressed is how many of these CAN genes must be targeted for efficient therapy of a tumour. On the basis of ageincidence data, some authors proposed that genetic alterations in 5-7 CAN genes may be required for solid tumour generation [19], and it is therefore expected that targeting of these genes or some of their downstream actor proteins may be therapeutically effective. We will 
Table 2 Drugs in clinical development against pathways identified in genomic/proteomic studies

$\begin{array}{ll}\text { Receptor Tyrosine Kinases } \\ \text { Pan-ErbB receptors } \\ \text { Cl-1033 } & \text { Pfizer } \\ \text { BIBW-2992 } & \text { Boehringer Ingelheim } \\ \text { Neratinib } & \text { Wyeth-Ayerst } \\ \text { MET } & \\ \text { MK-2461 } & \text { Merck } \\ \text { XL184 } & \text { Exelixis } \\ \text { MetMAb } & \text { Genentech } \\ \text { FGFR } & \\ \text { MK-2461 } & \text { Merck } \\ \text { Brivanib } & \text { BMS }\end{array}$

K-RAS-RAF

Plexxikon Inc/Roche

PI3K-AKT Inhibitors-mTOR

Dual PI3K-mTOR

$\begin{array}{ll}\text { BEZ235 } & \text { Novartis } \\ \text { XL765 } & \text { Exelixis } \\ \text { SF1126 } & \text { Semafore } \\ \text { BGT226 } & \text { Novartis }\end{array}$

PI3K Inhibitors

XL147 Exelixis

BKM120 Novartis

GDC0941 Genentech

AKT inhibitors

Perifosine Keryx

GSK690693 GSK

MK2206 Merck

mTOR

OSI027 OSI Pharmaceuticals

AZD8055 AstraZeneca

MAPK inhibitors

MEK Inhibitors

$\begin{array}{lll}\mathrm{Cl}-1040 & \text { Pfizer } & \text { phase } \mathrm{I} / \mathrm{I}[\mathrm{I8}, 79] \\ \text { AZD6244 } & \text { AstraZeneca } & \text { phase I/II80,81] } \\ \text { XL518 } & \text { Genentech } & \text { phase I[71] }\end{array}$

\section{Cell Cycle}

Flavopirido

SNS-032

R-547

Sanofi-aventis

BMS

Seleciclib

Roche

Cyclacel Pharmaceuticals

Histone Deacetylase inhibitors

$\begin{array}{ll}\begin{array}{l}\text { Vorinostat } \\ \text { (SAHA) }\end{array} & \text { Merck } \\ \text { Romidepsin } & \text { Gloucester Pharmaceuticals } \\ \text { MGCD0103 } & \text { MethylGene, Inc } \\ \text { LBH589 } & \text { Novartis }\end{array}$

Phase I/II86]

phase I/I[89]

phase $\mathbf{I} / \mid[90,91]$

phase I[68]

phase I/II[68,69]

phase II[68]

phase I[68]

phase I[68]

phase I[70,71]

phsae I/II72-74]

phase I[75-77]

phase I[68]

phase I[68]

phase $1 / \mid I[68]$

phase I/III[82]

phase I/II[31]

Phase $1 / I[83,84]$

Phase I/II[85]
Phase $|/| \mid[87,88]$

Table 2 Drugs in clinical development against pathways identified in genomic/proteomic studies (Continued)

Demethylating agents

$\begin{array}{lll}\begin{array}{l}\text { Azacitidine } \\ \text { Decitabine }\end{array} & \begin{array}{l}\text { Celgene } \\ \text { Eisai Pharmaceuticals }\end{array} & \begin{array}{l}\text { approved[92,93] } \\ \text { approved[94] }\end{array} \\ \begin{array}{l}\text { DNA repair } \\ \text { PARP }\end{array} & \\ \text { Olaparib } & \begin{array}{l}\text { KuDOS Pharmaceuticals/ } \\ \text { AstraZeneca }\end{array} & \text { phase II95] } \\ \text { AG-014699 } & \text { Pfizer } & \text { phase II96] } \\ \text { ATM } & & \\ \text { KU-55933 } & \text { KuDOS Pharmaceuticals } & \text { preclinical[97] }\end{array}$

Matrix Metalloproteinases

Neovastat Æterna Laboratories phase III[98,99]

Prinomastat Pfizer phase III

$[98,100,101]$

phase $1 / \|[30,66,67]$

comment later some biological studies that in fact support the use of a restricted number of targettable proteins that fall within that latter number.

Additional studies carried out in glioblastoma multiforme (GBM) [12,13] and pancreatic cancer [14], in addition to describing the somatic alterations in the DNA, advanced to more precisely defining the molecular pathways altered in these pathologies. Interestingly, in these tumours the number of mutated genes was lower (around 40 mutations/tumour) than in breast or colorectal cancer. By using similar and complementary techniques to search for point mutations, as well as gains and losses of genetic material, the two different reports analyzing the genomes of patients with GBM satisfyingly came to common conclusions $[12,13]$. These reports observed frequent alterations in three major signalling pathways that control cell proliferation: the receptor tyrosine kinase-PI3K route, the $\mathrm{p} 53$, and the retinoblastoma (RB) tumour suppressor pathways. Interestingly, some of these pathways were also found to participate in pancreatic as well as colon and breast cancer tumours, indicating overlapping of signalling pathways that may be critical in the genesis/progression of solid tumours. Interestingly also was the fact that mutations in the genome of GBM patients accumulated in patients treated with the alkylating agent temozolomide, a chemotherapeutic used in this pathology which is also highly mutagenic. Moreover, another study in which the genes coding for kinases of patients with several types of cancer were analyzed also showed that the highest prevalence of mutations in the kinases corresponded to GBM patients treated with temozolomide [20]. This indicates that resistance mechanisms may develop in 
these patients due to additive molecular alterations that favour the development of clones of cells resistant to the action of classical treatments. The sequencing efforts carried out in GBM also identified isocitrate dehydrogenase 1 (IDH1) as a protein that could act in the pathogenesis of this disease [13,21]. Interestingly, IDH1 was also found to be mutated in the genome of AML patients [18].

In lung cancer, using single nucleotide polymorphism (SNP) arrays, Weir et al. [9] analyzed the presence of copy-number alterations of chromosomal regions in a large proportion $(\mathrm{n}=371)$ of lung tumours, and found frequent gains or losses of chromosomal regions. Some genomic alterations, such as copy number gain of chromosome $5 \mathrm{p}$ occurred in a high number of patients (60\%). These alterations affected genes known to be frequently involved in lung cancer, such as EGFR/HER1, $C C N E 1$, or $K R A S$. In addition, the paper describes a novel player in lung cancer pathophysiology, the NKX21 gene product, a transcription factor implicated in the formation of lung pneumocytes. Knocking down the expression of this protein in NCI-H1925 lung cancer cells decreased their ability to grow in an anchoragedependent manner, indicating that this protein may represent a novel lung cancer promoting oncogene, and an interesting novel therapeutic target. Another report analyzed somatic mutations of 623 genes in 188 lung cancer samples [10]. These genes were selected for their already known implication in oncogenesis. KRAS or $E G F R$ were mutated in a substantial proportion of patients; but, in addition, several other genes not formerly associated to lung cancer were identified, and included tumour suppressors (NF1, RB, $A T M$, and $A P C)$, as well as tyrosine kinase genes (ERBB4, ephrin receptor genes, KDR, FGFR4, and NTRK). Of note, 132 of the 188 tumours had at least one mutation in genes that participate in MAPK signalling. Also, mutations in multiple genes of the Wnt pathway were observed in 29 of the 188 samples. Frequent mutations were also detected in DNA damage response genes, including TP53, and ATM. This clustering of mutations in certain pathways which play a role in oncogenesis points to the possibility of interfering with them for the treatment of lung tumours. Moreover, from a more ample perspective the molecular studies mentioned above open outstanding possibilities in terms of better focusing on certain targeted therapies for these tumours, based on drugs that target components of the identified signalling pathways. Another report confirmed the relevance of p53 and $\mathrm{Rb}$ in lung cancer [11]. Here the researchers sequenced the whole genome of a lung cancer cell line and found 22,910 somatic mutations, of which 134 were included into coding exons, 94 of them causing changes in the primary sequence of the coded proteins.
An ample study of somatic copy number alterations performed on 3131 tumour samples, and also using high resolution SNP arrays identified a median of 12 gains and loses in each patient tumour [22]. Frequent alterations in the control of cell cycle progression, apoptosis, DNA damage control, or kinase activity were reported.

\section{The contribution of functional genomics to cancer therapy}

A strategy that has been recently developed to massively identify potentially useful therapeutic targets is based on functional genomics studies using RNA-interference (RNAi) screenings. In one such functional screen based on the knockdown of 2,924 genes selected for their potential implication in tumour generation/progression, Schlabach et al. identified between $80-150$ gene products important for tumour survival/proliferation [23]. Of them, 19 genes were shared by the three distinct tumoral cell lines analyzed (two from colon cancer, and one from breast cancer). Interestingly, the list of the identified proteins showed significant overlap between distinct tumoral cell lines, but were different from those identified to be essential for the survival of normal breast epithelial cells [23]. This indicates the existence of qualitative differences between normal and malignant cells with respect to proteins that support their respective viabilities. This is highly relevant from the therapeutic point of view, as it indicates that the targeting of proteins that specifically support survival of cancer cells is realistic, and may spare normal cells, therefore representing an efficient and likely safe therapeutic strategy. In addition, these authors also found a certain degree of overlapping between proteins that support viability in tumours from the same tissue origin. However, they also found proteins whose function was required to sustain viability of one tumour cell, but did not play a critical survival role in others. Thus, knock down of the protein phosphatase PP1 seriously affected survival of HCC1954 colon cancer cell line, but did not substantially affect DLD-1 colon cancer cells. These results support the concept of the distinct susceptibility of different tumours, and stress the importance of adequately selecting protein targets to achieve therapeutic success. Analogous functional genomic studies in haematological malignancies led to the identification of the IRF4 and genes regulated by this protein as potential therapeutic targets in multiple myeloma [24], and the demonstration that tyrosine kinases play an important role in sustaining AML vitality [25]. This last work is particularly interesting as the authors used fresh samples from patients to identify, by also using RNAi techniques, potentially relevant drug targets. More ample RNAi screening techniques, based on the knockdown of up to 17,000 different genes [26], have allowed an almost 
universal analysis of the participation of the proteome in tumour survival, and have identified pathways and proteins that participate in tumour proliferation/survival [27].

In addition to finding potentially useful drug targets, these RNAi-based functional genomic screens have also been used to uncover mechanisms of drug resistance. Bernards and colleagues explored proteins involved in trastuzumab resistance in breast cancer and identified PTEN as one of the principal proteins whose lack of function was linked to trastuzumab resistance [28], in agreement to previous reports [29]. Moreover, preclinical data indicated that combination of agents that target HER2 and the PI3K route reverts resistance to trastuzumab [30].

In spite of the value of these studies, one of the potential pitfalls is the identification of relevant targets in vitro whose in vivo manipulation could be highly toxic. It is therefore mandatory to proceed into in vivo testing the manipulation of those targets (Figure 1).

\section{Biological findings support the use of combined targeted therapies}

An important aspect of the functional genomics assays is the finding of individual proteins whose targeting is deleterious for the tumoral cell, opening the door to the development of drugs that by interfering with their action may be therapeutically relevant as single agents. However, as mentioned above, the clinical experience suggests that efficient cancer treatment usually relies on the combination of agents that target distinct oncogenic networks. The fact that combination of agents may be more efficient than single agent treatment may be due to the heterogeneity of tumours, in some cases promoted by some anticancer treatments that either act as mutagens, as mentioned above in temozolomide-treated patients, or by the mutational heterogeneity within a single tumour. This heterogeneity has been recently proposed as a limit for the value of high throughput sequencing efforts in individual tumours [31]. The cross-talk between intracellular signalling pathways mainly activated by RTKs represents another reason to explain the efficacy of combination strategies. It has been reported that inhibition of certain pathways, such as the mTOR route may lead to increased MAPK activity [32]. Therefore, ablation of signals through both routes is required for efficient antitumoral action. Moreover, combined inhibition of PI3K and MAPK routes has shown superior antitumoral effect compared to individual targeting of either pathway [33].

Elegant biological studies supporting that adequate targeted drug combinations based on genomic profiling may be effective in cancer treatment has been offered by reports from the Massagué group [34,35]. These researchers used genomic and imaging techniques to analyze a particularly relevant property of tumoral cells, i.e. metastatic dissemination. Their strategy was based on the injection of a breast cancer cell line into the bloodstream of mice, and the selection of tumoral clones that homed to several organs. In their studies, genomic profiling identified signatures of genes that were particular of the cells that metastatized to a certain tissue. The researchers then selected some of these genes for further biological analyses, and suspected that four of them, Epiregulin, COX2, MMP1 and MMP2, represented therapeutic candidates in the case of lung metastases. In fact, experiments of gene knockdown confirmed the importance of these genes in breast cancer tumour growth in nude mice. Interestingly, single knockdown of only one of the coding mRNAs had little effect on the growth of these tumours as compared to double knockdowns. But the most impacting results were obtained by quadruple knockdowns. Reduction of the expression of the four mRNAs coding for the respective proteins fully abrogated tumour growth. These genomic-functional studies were complemented with targeted therapies aimed at neutralizing the activity of the four selected protein targets. Again, single agent treatment was less effective than combinations in preventing extravasation and lung colonization by the tumoral cells. Also, combination of three targeted agents, expected to neutralize the function of all four proteins, was more effective than dual combinations, and the triple combinations almost fully prevented lung invasion by the tumoral breast cancer cell population. Another recent analogous study identified a set of genes that mediate breast cancer metastasis to the brain [36]. Interestingly, some of them (COX2 and HB-EGF) share molecular identity or properties with those formerly described to participate in metastatic spreading to the lung. However, other proteins such as the sialystransferase ST6GALNAC5 was specific for cells that metastatized to the brain, and could be involved in facilitating cell passage through the blood brain barrier. The findings of Massagué and colleagues come in support of the well established clinical concept that drug combinations are superior in efficacy to single agents to treat solid tumours. The added value of their work is the use of molecular and biological tools to define and verify adequate targets for therapeutic intervention.

\section{Combined targeted therapies guided by proteomic studies}

Probably the genomic portraits are insufficient in guiding the selection of antitumoral therapies. Indeed, studies on receptor tyrosine kinase (RTK) targeting in cancer have offered insights into the convenience of complementing the genomic data with proteomic 


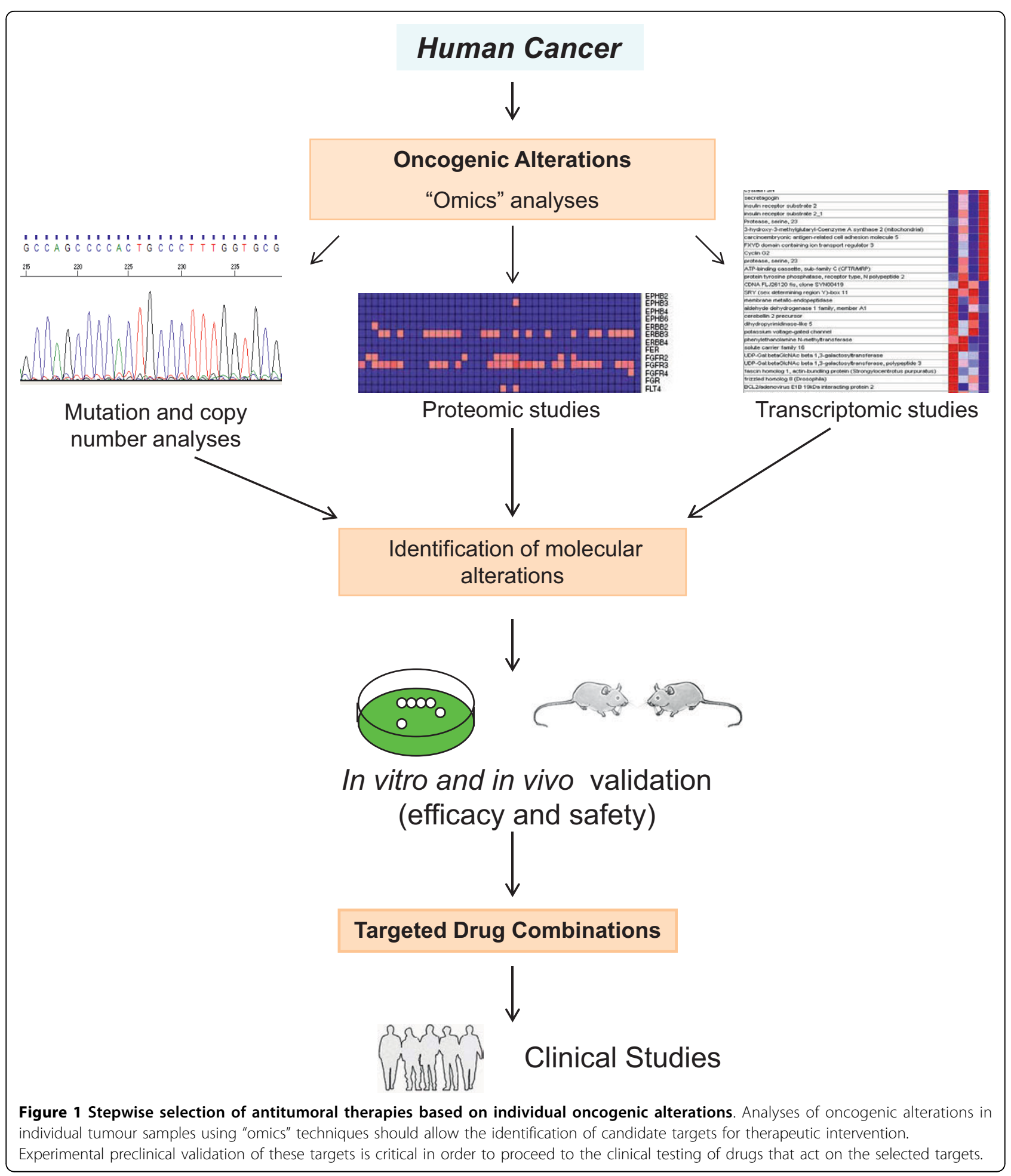

studies to establish efficient anticancer therapies. Stommel et al. [37] analyzed the phosphotyrosine content (indicative of activation) of 42 different RTKs in GBM. This disease may present alterations of the EGFR that result in its constitutive activation. However, response rates to agents that target exclusively the EGFR are poor. Stommel et al. found consistent activation of three or more RTKs in 19 out of $20 \mathrm{GBM}$ cell lines. These RTKs included the EGFR, ErbB3/HER3, platelet-derived growth factor receptor $\alpha$ (PDGFR $\alpha$ ), and MET. These 
researchers then explored the value of targeting these activated receptors using several in vitro models. Inhibition of the activity of individual receptors had a marginal effect on the growth properties of the GBM cell lines. However, combination of drugs that targeted two receptors was superior to single agent treatments. Furthermore, triple combinations were more efficient than double combinations, and practically abolished tumour growth in soft agar colony forming assays. The authors conclude that coactivation of multiple RTKs may sustain cell proliferation in GBM, and that adequate treatment of this pathology must include a careful evaluation of the RTKs activated.

In line with those findings, two additional reports showed the importance of targeting multiple RTKs in breast [38] and lung cancers [39]. Both studies attempted to identify the mechanisms of resistance to therapies that target HER (Human EGFR-like Receptors) receptors. In the breast cancer study, resistance to gefitinib or erlotinib, agents that act on the EGFR/HER1, was accompanied by increased tyrosine phosphorylation of ErbB3/HER3 [38]. Similarly, gefitinib resistance in lung cancer was also found to be accompanied by ErbB3/ HER3 signalling [39]. This up-regulation of ErbB3/HER3 signalling was due to amplification of MET. Concomitant treatment with gefitinib and the MET inhibitor PHA665752 provoked a decrease in cell survival not obtained by single drug treatments. The fact that multikinase inhibitors have reached the oncology clinic adds value to these experimental results and paves the way for the development of multikinase targeting strategies guided by proteomic analyses of the activation state of the kinome.

\section{Limitations of targeted therapies based on genomic profiling}

While the above mentioned studies offer unquestionable useful information about relevant targets for therapeutic intervention in cancer, several factors that can limit the efficacy of targeted therapies must be considered. One is the presence of molecular heterogeneity within a particular tumour [40]. The well known genetic instability of tumour cells may be responsible for the generation of different subclones of tumoral cells that could be represented at different amounts in the tumoral tissue (Figure 2 ). Those present in higher amounts are expected to be responsible for providing the genomic information, diluting the genomic landscapes of other tumoral cells present at lower amounts. The latter therefore escape detection by those genomic/proteomic analyses and result in tumour relapse, since targeted therapies are expected to focus on alterations present in the mostly abundant cells. Exemplifying this concept is the fact that chronic exposure to gefitinib, an agent that targets the
EGFR, results in emergence of resistant lung cancer cells bearing a mutation in the EGFR that renders these tumoral cells insensitive to the drug [41]. Presumably, cancer initiating/stem cells represent another source of failure to targeted treatments, as they are expected to represent a minority of the cellular constituents of the tumour. Strategies to identify drugs that target these tumour initiating cells are being developed and may represent useful additions to targeted therapies [42].

Another factor that limits the efficacy of targeted agents is the presence of parallel activation of downstream pathways. A well characterized example is the preclinical identification of the lack of antitumor activity of agents against RTKs when mutations at the K-RAS and PI3K genes were present $[43,44]$. Translation of these studies to the clinic confirmed lack of activity of anti-EGFR antibodies like cetuximab or panitumumab in colon cancer tumours with K-RAS mutations $[45,46]$. These studies have been of much importance in selection of anti-EGFR therapies in colorectal cancer, as patients whose tumours express mutated forms of K-RAS are now excluded from treatments based on anti-EGFR drugs. In addition, among colorectal tumours carrying wild-type KRAS, other additional mutations in genes participating in EGFR signalling may cause resistance to anti-EGFR therapies. Thus, mutation of BRAF or PIK3CA or loss of PTEN expression may result in resistance to EGFR-targeted monoclonal antibody treatment $[47,48]$.

Another important tumour component that is gaining importance as a targettable cell type is the stromal compartment. In multiple myeloma, a disease characterized by the accumulation of tumoral plasma cells, the interaction of these cells with the stroma is expected to be critical for sustaining survival of the myelomatous cells, and to provide drug resistance [49]. Moreover, treatments that target both the myeloma cell and the bone marrow microenvironment, such as the proteasome inhibitor bortezomib, or the immunomodulatory agents derived from thalidomide, have shown anti-myeloma activity and have reached the myeloma clinic [50]. Interestingly, genetic studies have demonstrated the presence of genetic alterations in the bone marrow mesenchymal cells of patients with multiple myeloma, supporting the concept that the stroma in the vicinity of the tumour may be cancerized [51]. In other neoplastic pathologies such as breast cancer, mesenchymal stem cells have been shown to promote metastatic dissemination of the tumoral cells [52]. Moreover, recent studies perfomed in myelodisplastic syndromes support the concept that initial alterations in the stromal compartment may favour the generation of secondary leukemias in a mouse model, further supporting a potential role of the stroma in the pathophysiology of at least certain 


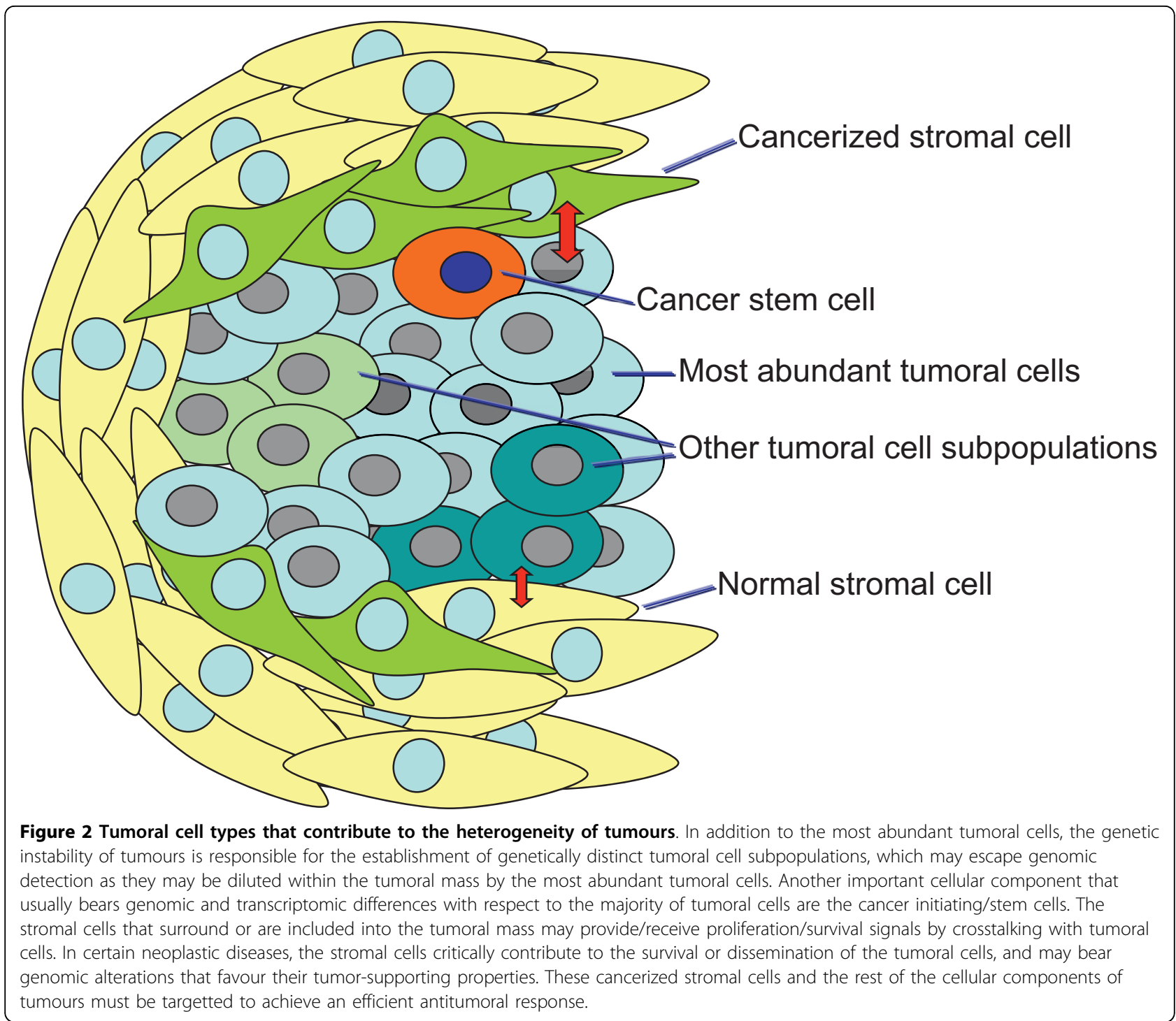

tumours [53]. Therefore, efficient antitumoral therapies must also take into consideration these variables in order to achieve long lasting remissions.

\section{Concluding remarks}

The power of high scale "omics" analyses coupled with the ample portfolio of targeted drugs under clinical development and already approved offers hope for a more effective and individualized anticancer therapy. It is rewarding to observe that sophisticated genomic, proteomic and biological studies reinforce the already known clinical strategy of using drug combinations to treat cancer patients (Figure 1). The molecular and biological data herewith commented also offers clues as to how many targets, pathways or functions should be attacked. The preclinical evidence that targeting from one to four proteins may impede proliferation, survival or invasion properties of cancer cells indicates that these cells depend on a limited number of proteins to carry out these biological functions. That the studies mentioned above have correctly targeted some of these molecules is beyond doubt. However, it is possible that targeting other proteins could have a similar impact. In fact, few overlap exists between the molecules targeted in each of these individual papers, especially those that used functional genomics to identify potential targets. This can be interpreted as to say that these papers have found "a set", (but not a unique "set") of targets that are therapeutically relevant. Finding a correct algorithm for the combination of drugs that target a set of proteins critical for sustaining cancer cells should be pursued.

In conclusion, recent results using new "omic" techniques support the future use of targeted drug combinations for the treatment of solid tumours. In our opinion 
to increase the efficiency of this process, it is critical to reach a close collaboration between academia, the pharmaceutical and biotechnological companies as well as regulatory authorities to develop rationale studies with drug combinations based on strong preclinical data.

\begin{abstract}
Acknowledgements
We thank Prof. I. Tannock for the critical reading of the manuscript, and suggestions. Work in AP lab receives support from the Ministry of Science and Education of Spain (BFU2006-01813/BMC and BFU2009-07728/BMC), from the ISCIII (RD06/0020/0041), and from the European Community through the regional development funding program (FEDER). AO receives support from the Spanish Association Against Cancer (AECC), from the FISCAM grant program PI2007/41 and Proyectos de Investigación en Salud (PS09/02144). The CIC receives institutional support from the Fundación Ramón Areces.
\end{abstract}

\section{Author details}

${ }^{1}$ Servicio de Oncología Médica, Complejo Hospitalario Universitario de Albacete y unidad AECC, Albacete, Spain. ${ }^{2}$ Drug Development Program, Princess Margaret Hospital, Toronto, Canada. ${ }^{3}$ Instituto de Biología Molecular y Celular del Cáncer, CSIC-Universidad de Salamanca, Salamanca, Spain.

\section{Authors' contributions}

Both authors contributed equally to the writing of the paper. Both authors also read and approved the final manuscript.

\section{Competing interests}

The authors declare that they have no competing interests.

Received: 5 May 2010 Accepted: 29 July 2010 Published: 29 July 2010

\section{References}

1. Sawyers CL: Chronic myeloid leukemia. N Engl J Med 1999, 340:1330-1340.

2. Druker BJ, Talpaz M, Resta DJ, Peng B, Buchdunger E, Ford JM, Lydon NB, Kantarjian H, Capdeville R, Ohno-Jones S, Sawyers CL: Efficacy and safety of a specific inhibitor of the BCR-ABL tyrosine kinase in chronic myeloid leukemia. N Engl J Med 2001, 344:1031-1037.

3. Hanahan D, Weinberg RA: The hallmarks of cancer. Cell 2000, 100:57-70.

4. Sawyers CL: Cancer: mixing cocktails. Nature 2007, 449:993-996.

5. Kwak EL, Clark JW, Chabner B: Targeted agents: the rules of combination. Clin Cancer Res 2007, 13:5232-5237.

6. Jia J, Zhu F, Ma X, Cao Z, Li Y, Chen YZ: Mechanisms of drug combinations: interaction and network perspectives. Nat Rev Drug Discov 2009, 8:111-128.

7. Wood LD, Parsons DW, Jones S, Lin J, Sjoblom T, Leary RJ, Shen D, Boca SM, Barber T, Ptak J, Silliman N, Szabo S, Dezso Z, Ustyanksky V, Nikolskaya T, Nikolsky Y, Karchin R, Wilson PA, Kaminker JS, Zhang Z, Croshaw R, Willis J, Dawson D, Shipitsin M, Willson JK, Sukumar S, Polyak K, Park BH, Pethiyagoda $\mathrm{CL}$, Pant PV, et al: The genomic landscapes of human breast and colorectal cancers. Science 2007, 318:1108-1113.

8. Leary RJ, Lin JC, Cummins J, Boca S, Wood LD, Parsons DW, Jones S, Sjoblom T, Park BH, Parsons R, Willis J, Dawson D, Willson JK, Nikolskaya T, Nikolsky $Y$, Kopelovich L, Papadopoulos N, Pennacchio LA, Wang TL, Markowitz SD, Parmigiani G, Kinzler KW, Vogelstein B, Velculescu VE: Integrated analysis of homozygous deletions focal amplifications and sequence alterations in breast and colorectal cancers. Proc Natl Acad SCi USA 2008, 105:16224-16229.

9. Weir BA, Woo MS, Getz G, Perner S, Ding L, Beroukhim R, Lin WM, Province MA, Kraja A, Johnson LA, Shah K, Sato M, Thomas RK, Barletta JA, Borecki IB, Broderick S, Chang AC, Chiang DY, Chirieac LR, Cho J, Fujii Y, Gazdar AF, Giordano T, Greulich H, Hanna M, Johnson BE, Kris MG, Lash A, Lin L, Lindeman $N$, et al: Characterizing the cancer genome in lung adenocarcinoma. Nature 2007, 450:893-898.

10. Ding L, Getz G, Wheeler DA, Mardis ER, McLellan MD, Cibulskis K, Sougnez C, Greulich H, Muzny DM, Morgan MB, Fulton L, Fulton RS, Zhang Q, Wendl MC, Lawrence MS, Larson DE, Chen K, Dooling DJ, Sabo A, Hawes AC, Shen H, Jhangiani SN, Lewis LR, Hall O, Zhu Y, Mathew T, Ren Y,
Yao J, Scherer SE, Clerc K, et al: Somatic mutations affect key pathways in lung adenocarcinoma. Nature 2008, 455:1069-1075.

11. Pleasance ED, Stephens PJ, O'Meara S, McBride DJ, Meynert A, Jones D, Lin ML, Beare D, Lau KW, Greenman C, Varela I, Nik-Zainal S, Davies HR, Ordonez GR, Mudie LJ, Latimer C, Edkins S, Stebbings L, Chen L, Jia M, Leroy C, Marshall J, Menzies A, Butler A, Teague JW, Mangion J, Sun YA, McLaughlin SF, Peckham HE, Tsung EF, et al: A small-cell lung cancer genome with complex signatures of tobacco exposure. Nature 463:184-190.

12. Comprehensive genomic characterization defines human glioblastoma genes and core pathways. Nature 2008, 455:1061-1068.

13. Parsons DW, Jones $S$, Zhang $X$, Lin JC, Leary RJ, Angenendt $P$, Mankoo P, Carter H, Siu IM, Gallia GL, Olivi A, McLendon R, Rasheed BA, Keir S, Nikolskaya T, Nikolsky Y, Busam DA, Tekleab H, Diaz LA Jr, Hartigan J, Smith DR, Strausberg RL, Marie SK, Shinjo SM, Yan H, Riggins GJ, Bigner DD, Karchin R, Papadopoulos N, Parmigiani G, et al: An integrated genomic analysis of human glioblastoma multiforme. Science 2008, 321:1807-1812.

14. Jones S, Zhang X, Parsons DW, Lin JC, Leary RJ, Angenendt P, Mankoo P, Carter H, Kamiyama H, Jimeno A, Hong SM, Fu B, Lin MT, Calhoun ES, Kamiyama M, Walter K, Nikolskaya T, Nikolsky Y, Hartigan J, Smith DR, Hidalgo M, Leach SD, Klein AP, Jaffee EM, Goggins M, Maitra A, lacobuzioDonahue C, Eshleman JR, Kern SE, Hruban RH, et al: Core signaling pathways in human pancreatic cancers revealed by global genomic analyses. Science 2008, 321:1801-1806.

15. Ocana A, Pandiella A: Identifying breast cancer druggable oncogenic alterations: leasons learned and future options. Clin Cancer Res 2008, 14:961-970.

16. Pleasance ED, Cheetham RK, Stephens PJ, McBride DJ, Humphray SJ, Greenman CD, Varela I, Lin ML, Ordonez GR, Bignell GR, Ye K, Alipaz J, Bauer MJ, Beare D, Butler A, Carter RJ, Chen L, Cox AJ, Edkins S, KokkoGonzales PI, Gormley NA, Grocock RJ, Haudenschild CD, Hims MM, James T, Jia M, Kingsbury Z, Leroy C, Marshall J, Menzies A, et al: A comprehensive catalogue of somatic mutations from a human cancer genome. Nature 463:191-196.

17. Ley TJ, Mardis ER, Ding L, Fulton B, McLellan MD, Chen K, Dooling D, Dunford-Shore BH, McGrath S, Hickenbotham M, Cook L, Abbott R, Larson DE, Koboldt DC, Pohl C, Smith S, Hawkins A, Abbott S, Locke D, Hillier LW, Miner T, Fulton L, Magrini V, Wylie T, Glasscock J, Conyers J, Sander N, Shi X, Osborne JR, Minx P, et al: DNA sequencing of a cytogenetically normal acute myeloid leukaemia genome. Nature 2008, 456:66-72.

18. Mardis ER, Ding L, Dooling DJ, Larson DE, McLellan MD, Chen K, Koboldt DC, Fulton RS, Delehaunty KD, McGrath SD, Fulton LA, Locke DP, Magrini VJ, Abbott RM, Vickery TL, Reed JS, Robinson JS, Wylie T, Smith SM, Carmichael L, Eldred JM, Harris CC, Walker J, Peck JB, Du F, Dukes AF, Sanderson GE, Brummett AM, Clark E, McMichael JF, et al: Recurring mutations found by sequencing an acute myeloid leukemia genome. $N$ Engl J Med 2009, 361:1058-1066.

19. Stratton MR, Campbell PJ, Futreal PA: The cancer genome. Nature 2009, 458:719-724.

20. Greenman C, Stephens P, Smith R, Dalgliesh GL, Hunter C, Bignell G, Davies H, Teague J, Butler A, Stevens C, Edkins S, O'Meara S, Vastrik I, Schmidt EE, Avis T, Barthorpe S, Bhamra G, Buck G, Choudhury B, Clements J, Cole J, Dicks E, Forbes S, Gray K, Halliday K, Harrison R, Hills K, Hinton J, Jenkinson A, Jones $D$, et al: Patterns of somatic mutation in human cancer genomes. Nature 2007, 446:153-158.

21. Yan H, Parsons DW, Jin G, McLendon R, Rasheed BA, Yuan W, Kos I, BatinicHaberle I, Jones S, Riggins GJ, Friedman H, Friedman A, Reardon D, Herndon J, Kinzler KW, Velculescu VE, Vogelstein B, Bigner DD: IDH1 and IDH2 mutations in gliomas. N Engl J Med 2009, 360:765-773.

22. Beroukhim R, Mermel CH, Porter D, Wei G, Raychaudhuri S, Donovan J, Barretina J, Boehm JS, Dobson J, Urashima M, Mc Henry KT, Pinchback RM, Ligon AH, Cho YJ, Haery L, Greulich H, Reich M, Winckler W, Lawrence MS, Weir BA, Tanaka KE, Chiang DY, Bass AJ, Loo A, Hoffman C, Prensner J, Liefeld T, Gao Q, Yecies D, Signoretti S, et al: The landscape of somatic copy-number alteration across human cancers. Nature 463:899-905.

23. Paddison PJ, Silva JM, Conklin DS, Schlabach M, Li M, Aruleba S, Balija V O'Shaughnessy A, Gnoj L, Scobie K, Chang K, Westbrook T, Cleary M, Sachidanandam R, McCombie WR, Elledge SJ, Hannon GJ: A resource for large-scale RNA-interference-based screens in mammals. Nature 2004, 428:427-431 
24. Shaffer AL, Emre NC, Lamy L, Ngo VN, Wright G, Xiao W, Powell J, Dave S, Yu X, Zhao H, Zeng Y, Chen B, Epstein J, Staudt LM: IRF4 addiction in multiple myeloma. Nature 2008, 454:226-231.

25. Tyner JW, Deininger MW, Loriaux MM, Chang BH, Gotlib JR, Willis SG, Erickson H, Kovacsovics T, O'Hare T, Heinrich MC, Druker BJ: RNAi screen for rapid therapeutic target identification in leukemia patients. Proc Natl Acad Sci USA 2009, 106:8695-8700.

26. Luo B, Cheung HW, Subramanian A, Sharifnia T, Okamoto M, Yang X, Hinkle G, Boehm JS, Beroukhim R, Weir BA, Mermel C, Barbie DA, Awad T, Zhou X, Nguyen T, Piqani B, Li C, Golub TR, Meyerson M, Hacohen N, Hahn WC, Lander ES, Sabatini DM, Root DE: Highly parallel identification of essential genes in cancer cells. Proc Natl Acad Sci USA 2008, 105:20380-20385.

27. Barbie DA, Tamayo P, Boehm JS, Kim SY, Moody SE, Dunn IF, Schinzel AC, Sandy P, Meylan E, Scholl C, Frohling S, Chan EM, Sos ML, Michel K, Mermel C, Silver SJ, Weir BA, Reiling JH, Sheng Q, Gupta PB, Wadlow RC, Le H, Hoersch S, Wittner BS, Ramaswamy S, Livingston DM, Sabatini DM, Meyerson M, Thomas RK, Lander ES, et al: Systematic RNA interference reveals that oncogenic KRAS-driven cancers require TBK1. Nature 2009, 462:108-112.

28. Berns K, Horlings HM, Hennessy BT, Madiredjo M, Hijmans EM, Beelen K, Linn SC, Gonzalez-Angulo AM, Stemke-Hale K, Hauptmann M, Beijersbergen RL, Mills GB, van de Vijver MJ, Bernards R: A functional genetic approach identifies the PI3K pathway as a major determinant of trastuzumab resistance in breast cancer. Cancer Cell 2007, 12:395-402.

29. Nagata Y, Lan KH, Zhou X, Tan M, Esteva FJ, Sahin AA, Klos KS, Li P, Monia BP, Nguyen NT, Hortobagyi GN, Hung MC, Yu D: PTEN activation contributes to tumor inhibition by trastuzumab and loss of PTEN predicts trastuzumab resistance in patients. Cancer Cell 2004, 6:117-127.

30. Eichhorn PJ, Gili M, Scaltriti M, Serra V, Guzman M, Nijkamp W, Beijersbergen RL, Valero V, Seoane J, Bernards R, Baselga J: Phosphatidylinositol 3-kinase hyperactivation results in lapatinib resistance that is reversed by the mTOR/phosphatidylinositol 3-kinase inhibitor NVP-BEZ235. Cancer Res 2008, 68:9221-9230.

31. Chen R, Wierda WG, Chubb S, Hawtin RE, Fox JA, Keating MJ, Gandhi V, Plunkett W: Mechanism of action of SNS-032, a novel cyclin-dependent kinase inhibitor in chronic lymphocytic leukemia. Blood 2009, 113:4637-4645.

32. Carracedo A, Ma L, Teruya-Feldstein J, Rojo F, Salmena L, Alimonti A, Egia A, Sasaki AT, Thomas G, Kozma SC, Papa A, Nardella C, Cantley LC, Baselga J, Pandolfi PP: Inhibition of mTORC1 leads to MAPK pathway activation through a PI3K-dependent feedback loop in human cancer. $J$ Clin Invest 2008, 118:3065-3074.

33. Hoeflich KP, O'Brien C, Boyd Z, Cavet G, Guerrero S, Jung K, Januario T, Savage H, Punnoose E, Truong T, Zhou W, Berry L, Murray L, Amler L, Belvin $M$, Friedman $L S$, Lackner MR: In vivo antitumor activity of MEK and phosphatidylinositol 3-kinase inhibitors in basal-like breast cancer models. Clin Cancer Res 2009, 15:4649-4664.

34. Gupta GP, Nguyen DX, Chiang AC, Bos PD, Kim JY, Nadal C, Gomis RR, Manova-Todorova K, Massague J: Mediators of vascular remodelling coopted for sequential steps in lung metastasis. Nature 2007, 446:765-770,

35. Minn AJ, Gupta GP, Siegel PM, Bos PD, Shu W, Giri DD, Viale A, Olshen AB, Gerald WL, Massague J: Genes that mediate breast cancer metastasis to lung. Nature 2005, 436:518-524.

36. Bos PD, Zhang XH, Nadal C, Shu W, Gomis RR, Nguyen DX, Minn AJ, van de Vijver MJ, Gerald WL, Foekens JA, Massague J: Genes that mediate breast cancer metastasis to the brain. Nature 2009, 459:1005-1009.

37. Stommel $J M$, Kimmelman $A C$, Ying $H$, Nabioullin $R$, Ponugoti $A H$, Wiedemeyer R, Stegh AH, Bradner JE, Ligon KL, Brennan C, Chin L, DePinho RA: Coactivation of receptor tyrosine kinases affects the response of tumor cells to targeted therapies. Science 2007, 318:287-290

38. Sergina NV, Rausch M, Wang D, Blair J, Hann B, Shokat KM, Moasser MM: Escape from HER-family tyrosine kinase inhibitor therapy by the kinaseinactive HER3. Nature 2007, 445:437-441.

39. Engelman JA, Zejnullahu K, Mitsudomi T, Song Y, Hyland C, Park JO, Lindeman N, Gale CM, Zhao X, Christensen J, Kosaka T, Holmes AJ, Rogers AM, Cappuzzo F, Mok T, Lee C, Johnson BE, Cantley LC, Janne PA: MET amplification leads to gefitinib resistance in lung cancer by activating ERBB3 signaling. Science 2007, 316:1039-1043.

40. Fox EJ, Salk JJ, Loeb LA: Cancer genome sequencing-an interim analysis. Cancer Res 2009, 69:4948-4950.
41. Engelman JA, Mukohara T, Zejnullahu K, Lifshits E, Borras AM, Gale CM, Naumov GN, Yeap BY, Jarrell E, Sun J, Tracy S, Zhao X, Heymach JV, Johnson BE, Cantley LC, Janne PA: Allelic dilution obscures detection of a biologically significant resistance mutation in EGFR-amplified lung cancer. J Clin Invest 2006, 116:2695-2706.

42. Gupta PB, Onder TT, Jiang G, Tao K, Kuperwasser C, Weinberg RA, Lander ES: Identification of selective inhibitors of cancer stem cells by high-throughput screening. Cell 2009, 138:645-659.

43. Benvenuti S, Sartore-Bianchi A, Di Nicolantonio F, Zanon C, Moroni M, Veronese S, Siena S, Bardelli A: Oncogenic activation of the RAS/RAF signaling pathway impairs the response of metastatic colorectal cancers to anti-epidermal growth factor receptor antibody therapies. Cancer Res 2007, 67:2643-2648.

44. Junttila TT, Akita RW, Parsons K, Fields C, Lewis Phillips GD, Friedman LS, Sampath D, Sliwkowski MX: Ligand-independent HER2/HER3/PI3K complex is disrupted by trastuzumab and is effectively inhibited by the PI3K inhibitor GDC-0941. Cancer Cell 2009, 15:429-440.

45. Karapetis CS, Khambata-Ford S, Jonker DJ, O'Callaghan CJ, Tu D, Tebbutt NC, Simes RJ, Chalchal H, Shapiro JD, Robitaille S, Price TJ, Shepherd L, Au HJ, Langer C, Moore MJ, Zalcberg JR: K-ras mutations and benefit from cetuximab in advanced colorectal cancer. $N$ Engl I Med 2008, 359:1757-1765.

46. Amado RG, Wolf $M$, Peeters $M$, Van Cutsem E, Siena S, Freeman DJ, Juan $T$, Sikorski R, Suggs S, Radinsky R, Patterson SD, Chang DD: Wild-type KRAS is required for panitumumab efficacy in patients with metastatic colorectal cancer. J Clin Oncol 2008, 26:1626-1634.

47. Siena S, Sartore-Bianchi A, Di Nicolantonio F, Balfour J, Bardelli A: Biomarkers predicting clinical outcome of epidermal growth factor receptor-targeted therapy in metastatic colorectal cancer. J Natl Cancer Inst 2009, 101:1308-1324

48. De Roock W, Claes B, Bernasconi D, De Schutter J, Biesmans B, Fountzilas G, Kalogeras KT, Kotoula V, Papamichael D, Laurent-Puig P, Penault-Llorca F, Rougier P, Vincenzi B, Santini D, Tonini G, Cappuzzo F, Frattini M, Molinari F, Saletti P, De Dosso S, Martini M, Bardelli A, Siena S, Sartore-Bianchi A, Tabernero J, Macarulla T, Di Fiore F, Gangloff AO, Ciardiello F, Pfeiffer P, et al: Effects of KRAS BRAF, NRAS and PIK3CA mutations on the efficacy of cetuximab plus chemotherapy in chemotherapy-refractory metastatic colorectal cancer: a retrospective consortium analysis. Lancet Oncol 2010.

49. McMillin DW, Delmore J, Weisberg E, Negri JM, Geer DC, Klippel S, Mitsiades N, Schlossman RL, Munshi NC, Kung AL, Griffin JD, Richardson PG, Anderson KC, Mitsiades CS: Tumor cell-specific bioluminescence platform to identify stroma-induced changes to anticancer drug activity. Nat Med 16:483-489.

50. Ocio EM, Mateos MV, Maiso P, Pandiella A, San-Miguel JF: New drugs in multiple myeloma: mechanisms of action and phase I//l clinical findings. Lancet Oncol 2008, 9:1157-1165.

51. Garayoa M, Garcia JL, Santamaria C, Garcia-Gomez A, Blanco JF, Pandiella A, Hernandez JM, Sanchez-Guijo FM, del Canizo MC, Gutierrez NC, San Miguel JF: Mesenchymal stem cells from multiple myeloma patients display distinct genomic profile as compared with those from normal donors. Leukemia 2009, 23:1515-1527.

52. Karnoub AE, Dash AB, Vo AP, Sullivan A, Brooks MW, Bell GW, Richardson AL, Polyak K, Tubo R, Weinberg RA: Mesenchymal stem cells within tumour stroma promote breast cancer metastasis. Nature 2007, 449:557-563.

53. Raaijmakers $\mathrm{MH}$, Mukherjee $\mathrm{S}$, Guo $\mathrm{S}$, Zhang $\mathrm{S}$, Kobayashi $T$, Schoonmaker JA, Ebert BL, Al-Shahrour F, Hasserjian RP, Scadden EO, Aung Z, Matza M, Merkenschlager M, Lin C, Rommens JM, Scadden DT: Bone progenitor dysfunction induces myelodysplasia and secondary leukaemia. Nature 464:852-857.

54. Sugarbaker DJ, Richards WG, Gordon GJ, Dong L, De Rienzo A, Maulik G, Glickman JN, Chirieac LR, Hartman ML, Taillon BE, Du L, Bouffard P, Kingsmore SF, Miller NA, Farmer AD, Jensen RV, Gullans SR, Bueno R: Transcriptome sequencing of malignant pleural mesothelioma tumors. Proc Natl Acad Sci USA 2008, 105:3521-3526.

55. Dalgliesh GL, Furge K, Greenman C, Chen L, Bignell G, Butler A, Davies H, Edkins S, Hardy C, Latimer C, Teague J, Andrews J, Barthorpe S, Beare D, Buck G, Campbell PJ, Forbes S, Jia M, Jones D, Knott H, Kok CY, Lau KW, Leroy C, Lin ML, McBride DJ, Maddison M, Maguire S, McLay K, Menzies A, Mironenko $T$, et al: Systematic sequencing of renal carcinoma reveals inactivation of histone modifying genes. Nature 463:360-363. 
56. Shah SP, Kobel M, Senz J, Morin RD, Clarke BA, Wiegand KC, Leung G, Zayed A, Mehl E, Kalloger SE, Sun M, Giuliany R, Yorida E, Jones S, Varhol R, Swenerton KD, Miller D, Clement PB, Crane C, Madore J, Provencher D, Leung P, DeFazio A, Khattra J, Turashvili G, Zhao Y, Zeng T, Glover JN, Vanderhyden B, Zhao C, et al: Mutation of FOXL2 in granulosa-cell tumors of the ovary. N Engl J Med 2009, 360:2719-2729.

57. Ocana A, Amir E: Irreversible pan-ErbB tyrosine kinase inhibitors and breast cancer: Current status and future directions. Cancer Treat Rev 2009, 35:686-691.

58. Erlichman C, Boerner SA, Hallgren CG, Spieker $R$, Wang XY, James $C D$, Scheffer GL, Maliepaard M, Ross DD, Bible KC, Kaufmann SH: The HER tyrosine kinase inhibitor $\mathrm{Cl} 1033$ enhances cytotoxicity of 7-ethyl-10hydroxycamptothecin and topotecan by inhibiting breast cancer resistance protein-mediated drug efflux. Cancer Res 2001, 61:739-748.

59. Perera SA, Li D, Shimamura T, Raso MG, Ji H, Chen L, Borgman CL, Zaghlul S, Brandstetter KA, Kubo S, Takahashi M, Chirieac LR, Padera RF, Bronson RT, Shapiro Gl, Greulich H, Meyerson M, Guertler U, Chesa PG, Solca F, Wistuba II, Wong KK: HER2YVMA drives rapid development of adenosquamous lung tumors in mice that are sensitive to BIBW2992 and rapamycin combination therapy. Proc Natl Acad Sci USA 2009, 106:474-479.

60. Rabindran SK, Discafani CM, Rosfjord EC, Baxter M, Floyd MB, Golas J, Hallett WA, Johnson BD, Nilakantan R, Overbeek E, Reich MF, Shen R, Shi X, Tsou HR, Wang YF, Wissner A: Antitumor activity of HKI-272, an orally active irreversible inhibitor of the HER-2 tyrosine kinase. Cancer Res 2004, 64:3958-3965.

61. Wong KK, Fracasso PM, Bukowski RM, Lynch TJ, Munster PN, Shapiro Gl, Janne PA, Eder JP, Naughton MJ, Ellis MJ, Jones SF, Mekhail T, Zacharchuk C, Vermette J, Abbas R, Quinn S, Powell C, Burris HA: A phase I study with neratinib (HKI-272), an irreversible pan ErbB receptor tyrosine kinase inhibitor in patients with solid tumors. Clin Cancer Res 2009, 15:2552-2558

62. Eder JP, Vande Woude GF, Boerner SA, LoRusso PM: Novel therapeutic inhibitors of the c-Met signaling pathway in cancer. Clin Cancer Res 2009, $15: 2207-2214$

63. Jin $\mathrm{H}$, Yang R, Zheng Z, Romero M, Ross J, Bou-Reslan H, Carano RA, Kasman I, Mai E, Young J, Zha J, Zhang Z, Ross S, Schwall R, Colbern G, Merchant M: MetMAb, the one-armed 5D5 anti-c-Met antibody inhibits orthotopic pancreatic tumor growth and improves survival. Cancer Res 2008, 68:4360-4368.

64. Ayers M, Fargnoli J, Lewin A, Wu Q, Platero JS: Discovery and validation of biomarkers that respond to treatment with brivanib alaninate a smallmolecule VEGFR-2/FGFR-1 antagonist. Cancer Res 2007, 67:6899-6906.

65. Sala E, Mologni L, Truffa S, Gaetano C, Bollag GE, Gambacorti-Passerini C: BRAF silencing by short hairpin RNA or chemical blockade by PLX4032 leads to different responses in melanoma and thyroid carcinoma cells. Mol Cancer Res 2008, 6:751-759.

66. Maira SM, Stauffer F, Brueggen J, Furet P, Schnell C, Fritsch C, Brachmann S, Chene P, De Pover A, Schoemaker K, Fabbro D, Gabriel D, Simonen M, Murphy L, Finan P, Sellers W, Garcia-Echeverria C: Identification and characterization of NVP-BEZ235, a new orally available dual phosphatidylinositol 3-kinase/mammalian target of rapamycin inhibitor with potent in vivo antitumor activity. Mol Cancer Ther 2008, 7:1851-1863.

67. Serra V, Markman B, Scaltriti M, Eichhorn PJ, Valero V, Guzman M, Botero ML, Llonch E, Atzori F, Di Cosimo S, Maira M, Garcia-Echeverria C, Parra JL, Arribas J, Baselga J: NVP-BEZ235, a dual PI3K/mTOR inhibitor prevents PI3K signaling and inhibits the growth of cancer cells with activating PI3K mutations. Cancer Res 2008, 68:8022-8030.

68. Engelman JA: Targeting PI3K signalling in cancer: opportunities challenges and limitations. Nat Rev Cancer 2009, 9:550-562.

69. Garlich JR, De P, Dey N, Su JD, Peng X, Miller A, Murali R, Lu Y, Mills GB, Kundra V, Shu HK, Peng Q, Durden DL: A vascular targeted pan phosphoinositide 3-kinase inhibitor prodrug, SF1126 with antitumor and antiangiogenic activity. Cancer Res 2008, 68:206-215.

70. Edgar KA, Wallin JJ, Berry M, Lee LB, Prior WW, Sampath D, Friedman LS, Belvin M: Isoform-specific phosphoinositide 3-kinase inhibitors exert distinct effects in solid tumors. Cancer Res 70:1164-1172.

71. Study Evaluating HKI-272 in Combination With Vinorelbine in Subjects With Solid Tumors and Metastatic Breast Cancer. [http://clinicaltrialsgov/ ct2/show/NCT00706030], Accessed March 25, 2010.
72. Kondapaka SB, Singh SS, Dasmahapatra GP, Sausville EA, Roy KK: Perifosine, a novel alkylphospholipid inhibits protein kinase B activation. Mol Cancer Ther 2003, 2:1093-1103.

73. Hideshima T, Catley L, Yasui H, Ishitsuka K, Raje N, Mitsiades C, Podar K, Munshi NC, Chauhan D, Richardson PG, Anderson KC: Perifosine, an oral bioactive novel alkylphospholipid inhibits Akt and induces in vitro and in vivo cytotoxicity in human multiple myeloma cells. Blood 2006, 107:4053-4062.

74. Van Ummersen L, Binger K, Volkman J, Marnocha R, Tutsch K, Kolesar J, Arzoomanian R, Alberti D, Wilding G: A phase I trial of perifosine (NSC 639966) on a loading dose/maintenance dose schedule in patients with advanced cancer. Clin Cancer Res 2004, 10:7450-7456.

75. Rhodes N, Heerding DA, Duckett DR, Eberwein DJ, Knick VB, Lansing TJ, McConnell RT, Gilmer TM, Zhang SY, Robell K, Kahana JA, Geske RS, Kleymenova EV, Choudhry AE, Lai Z, Leber JD, Minthorn EA, Strum SL, Wood ER, Huang PS, Copeland RA, Kumar R: Characterization of an Akt kinase inhibitor with potent pharmacodynamic and antitumor activity. Cancer Res 2008, 68:2366-2374.

76. Heerding DA, Rhodes N, Leber JD, Clark TJ, Keenan RM, Lafrance LV, Li M, Safonov IG, Takata DT, Venslavsky JW, Yamashita DS, Choudhry AE, Copeland RA, Lai Z, Schaber MD, Tummino PJ, Strum SL, Wood ER, Duckett DR, Eberwein D, Knick VB, Lansing TJ, McConnell RT, Zhang S, Minthorn EA, Concha NO, Warren GL, Kumar R: Identification of 4-(2-(4amino-1,2,5-oxadiazol-3-yl)-1-ethyl-7-\{[(3S)-3-piperidinylmethyl]o xy\}-1 Himidazo[4,5-c]pyridin-4-yl)-2-methyl-3-butyn-2-ol (GSK690693), a novel inhibitor of AKT kinase. J Med Chem 2008, 51:5663-5679.

77. Levy DS, Kahana JA, Kumar R: AK Tinhibitor GSK690693 induces growth inhibition and apoptosis in acute lymphoblastic leukemia cell lines. Blood 2009, 113:1723-1729.

78. Lorusso PM, Adjei AA, Varterasian M, Gadgeel S, Reid J, Mitchell DY, Hanson L, DeLuca P, Bruzek L, Piens J, Asbury P, Van Becelaere K, Herrera R, Sebolt-Leopold J, Meyer MB: Phase I and pharmacodynamic study of the oral MEK inhibitor $\mathrm{Cl}-1040$ in patients with advanced malignancies. J Clin Oncol 2005, 23:5281-5293.

79. Rinehart J, Adjei AA, Lorusso PM, Waterhouse D, Hecht JR, Natale RB, Hamid O, Varterasian M, Asbury P, Kaldjian EP, Gulyas S, Mitchell DY, Herrera R, Sebolt-Leopold JS, Meyer MB: Multicenter phase II study of the oral MEK inhibitor $\mathrm{Cl}-1040$ in patients with advanced non-small-cell lung breast, colon and pancreatic cancer. J Clin Oncol 2004, 22:4456-4462.

80. Adjei AA, Cohen RB, Franklin W, Morris C, Wilson D, Molina JR, Hanson L, Gore L, Chow L, Leong S, Maloney L, Gordon G, Simmons H, Marlow A, Litwiler K, Brown S, Poch G, Kane K, Haney J, Eckhardt SG: Phase I pharmacokinetic and pharmacodynamic study of the oral smallmolecule mitogen-activated protein kinase kinase 1/2 inhibitor AZD6244 (ARRY-142886) in patients with advanced cancers. J Clin Oncol 2008, 26:2139-2146.

81. Board RE, Ellison G, Orr MC, Kemsley KR, McWalter G, Blockley LY, Dearden SP, Morris C, Ranson M, Cantarini MV, Dive C, Hughes A: Detection of BRAF mutations in the tumour and serum of patients enrolled in the AZD6244 (ARRY-142886) advanced melanoma phase II study. Br I Cancer 2009, 101:1724-1730.

82. Chen R, Keating MJ, Gandhi V, Plunkett W: Transcription inhibition by flavopiridol: mechanism of chronic lymphocytic leukemia cell death. Blood 2005, 106:2513-2519.

83. Chu XJ, DePinto W, Bartkovitz D, So SS, Vu BT, Packman K, Lukacs C, Ding $Q$, Jiang N, Wang $K$, Goelzer P, Yin X, Smith MA, Higgins BX, Chen Y, Xiang Q, Moliterni J, Kaplan G, Graves B, Lovey A, Fotouhi N: Discovery of [4-Amino-2-(1-methanesulfonylpiperidin-4-ylamino)pyrimidin-5-yl](2,3diflu oro-6-methoxyphenyl)methanone (R547), a potent and selective cyclin-dependent kinase inhibitor with significant in vivo antitumor activity. J Med Chem 2006, 49:6549-6560.

84. DePinto W, Chu XJ, Yin X, Smith M, Packman K, Goelzer P, Lovey A, Chen Y, Qian H, Hamid R, Xiang Q, Tovar C, Blain R, Nevins T, Higgins B, Luistro L, Kolinsky K, Felix B, Hussain S, Heimbrook D: In vitro and in vivo activity of R547: a potent and selective cyclin-dependent kinase inhibitor currently in phase I clinical trials. Mol Cancer Ther 2006, 5:2644-2658.

85. Galimberti F, Thompson SL, Liu X, Li H, Memoli V, Green SR, DiRenzo J, Greninger P, Sharma SV, Settleman J, Compton DA, Dmitrovsky E: Targeting the cyclin E-Cdk-2 complex represses lung cancer growth by triggering anaphase catastrophe. Clin Cancer Res 16:109-120. 
86. O'Connor OA, Heaney ML, Schwartz L, Richardson S, Willim R, MacGregorCortelli B, Curly T, Moskowitz C, Portlock C, Horwitz S, Zelenetz AD, Frankel S, Richon V, Marks P, Kelly WK: Clinical experience with intravenous and oral formulations of the novel histone deacetylase inhibitor suberoylanilide hydroxamic acid in patients with advanced hematologic malignancies. J Clin Oncol 2006, 24:166-173.

87. Klimek VM, Fircanis S, Maslak P, Guernah I, Baum M, Wu N, Panageas K, Wright JJ, Pandolfi PP, Nimer SD: Tolerability, pharmacodynamics and pharmacokinetics studies of depsipeptide (romidepsin) in patients with acute myelogenous leukemia or advanced myelodysplastic syndromes. Clin Cancer Res 2008, 14:826-832.

88. Piekarz RL, Robey R, Sandor V, Bakke S, Wilson WH, Dahmoush L, Kingma DM, Turner ML, Altemus R, Bates SE: Inhibitor of histone deacetylation depsipeptide (FR901228), in the treatment of peripheral and cutaneous T-cell lymphoma: a case report. Blood 2001, 98:2865-2868.

89. Garcia-Manero G, Yang H, Bueso-Ramos C, Ferrajoli A, Cortes J, Wierda WG, Faderl S, Koller C, Morris G, Rosner G, Loboda A, Fantin VR, Randolph SS, Hardwick JS, Reilly JF, Chen C, Ricker JL, Secrist JP, Richon VM, Frankel SR, Kantarjian HM: Phase 1 study of the histone deacetylase inhibitor vorinostat (suberoylanilide hydroxamic acid [SAHA]) in patients with advanced leukemias and myelodysplastic syndromes. Blood 2008, 111:1060-1066.

90. Giles F, Fischer T, Cortes J, Garcia-Manero G, Beck J, Ravandi F, Masson E, Rae P, Laird G, Sharma S, Kantarjian H, Dugan M, Albitar M, Bhalla K: A phase I study of intravenous LBH589, a novel cinnamic hydroxamic acid analogue histone deacetylase inhibitor in patients with refractory hematologic malignancies. Clin Cancer Res 2006, 12:4628-4635.

91. Ellis L, Pan Y, Smyth GK, George DJ, McCormack C, Williams-Truax R, Mita M, Beck J, Burris H, Ryan G, Atadja P, Butterfoss D, Dugan M, Culver K, Johnstone RW, Prince HM: Histone deacetylase inhibitor panobinostat induces clinical responses with associated alterations in gene expression profiles in cutaneous T-cell lymphoma. Clin Cancer Res 2008, 14:4500-4510.

92. Fenaux P, Mufti GJ, Hellstrom-Lindberg E, Santini V, Finelli C, Giagounidis A, Schoch R, Gattermann N, Sanz G, List A, Gore SD, Seymour JF, Bennett JM, Byrd J, Backstrom J, Zimmerman L, McKenzie D, Beach C, Silverman LR: Efficacy of azacitidine compared with that of conventional care regimens in the treatment of higher-risk myelodysplastic syndromes: a randomised open-label, phase III study. Lancet Oncol 2009, 10:223-232.

93. Silverman LR, Demakos EP, Peterson BL, Kornblith AB, Holland JC, Odchimar-Reissig R, Stone RM, Nelson D, Powell BL, DeCastro CM, Ellerton J, Larson RA, Schiffer CA, Holland JF: Randomized controlled trial of azacitidine in patients with the myelodysplastic syndrome: a study of the cancer and leukemia group B. J Clin Oncol 2002, 20:2429-2440.

94. Kantarjian H, Issa JP, Rosenfeld CS, Bennett JM, Albitar M, DiPersio J, Klimek V, Slack J, de Castro C, Ravandi F, Helmer R, Shen L, Nimer SD, Leavitt R, Raza A, Saba H: Decitabine improves patient outcomes in myelodysplastic syndromes: results of a phase III randomized study. Cancer 2006, 106:1794-1803.

95. Fong PC, Boss DS, Yap TA, Tutt A, Wu P, Mergui-Roelvink M, Mortimer $P$, Swaisland H, Lau A, O'Connor MJ, Ashworth A, Carmichael J, Kaye SB, Schellens JH, de Bono JS: Inhibition of poly(ADP-ribose) polymerase in tumors from BRCA mutation carriers. N Engl J Med 2009, 361:123-134.

96. Plummer R, Jones C, Middleton M, Wilson R, Evans J, Olsen A, Curtin N, Boddy A, McHugh P, Newell D, Harris A, Johnson P, Steinfeldt H, Dewji R, Wang D, Robson L, Calvert H: Phase I study of the poly(ADP-ribose) polymerase inhibitor AG014699 in combination with temozolomide in patients with advanced solid tumors. Clin Cancer Res 2008, 14:7917-7923.

97. Hickson I, Zhao Y, Richardson CJ, Green SJ, Martin NM, Orr Al, Reaper PM, Jackson SP, Curtin NJ, Smith GC: Identification and characterization of a novel and specific inhibitor of the ataxia-telangiectasia mutated kinase ATM. Cancer Res 2004, 64:9152-9159.

98. Roy R, Yang J, Moses MA: Matrix metalloproteinases as novel biomarkers and potential therapeutic targets in human cancer. J Clin Oncol 2009, 27:5287-5297.

99. Latreille J, Batist G, Laberge F, Champagne P, Croteau D, Falardeau P, Levinton C, Hariton C, Evans WK, Dupont E: Phase I/II trial of the safety and efficacy of AE-941 (Neovastat) in the treatment of non-small-cell lung cancer. Clin Lung Cancer 2003, 4:231-236.

100. Bissett D, O'Byrne K, von Pawel J, Gatzemeier U, Price A, Nicolson M, Mercier R, Mazabel E, Penning C, Zhang MH, Collier MA, Shepherd FA:
Phase III study of matrix metalloproteinase inhibitor prinomastat in nonsmall-cell lung cancer. J Clin Oncol 2005, 23:842-849.

101. Hande KR, Collier M, Paradiso L, Stuart-Smith J, Dixon M, Clendeninn N, Yeun G, Alberti D, Binger K, Wilding G: Phase I and pharmacokinetic study of prinomastat a matrix metalloprotease inhibitor. Clin Cancer Res 2004, 10:909-915.

doi:10.1186/1476-4598-9-202

Cite this article as: Ocaña and Pandiella: Personalized therapies in the cancer "omics" era. Molecular Cancer 2010 9:202.

\section{Submit your next manuscript to BioMed Central and take full advantage of:}

- Convenient online submission

- Thorough peer review

- No space constraints or color figure charges

- Immediate publication on acceptance

- Inclusion in PubMed, CAS, Scopus and Google Scholar

- Research which is freely available for redistribution

Submit your manuscript at www.biomedcentral.com/submit
C Biomed Central 